\title{
Humic and fulvic acids: sink or source in the availability of metals to the marine bivalves Macoma balthica and Potamocorbula amurensis?
}

\author{
Alan W. Decho*, Samuel N. Luoma \\ U.S. Geological Survey, MS 465, 345 Middlefield Rd, Menlo Park, California 94025, USA
}

\begin{abstract}
Humic acids (HA) and fulvic acids (FA) are common forms of organic matter in marine sediments, and are routinely ingested by deposit- and suspension-feeding animals. These compounds may be a sink for metals, implying that once metals are bound to humic substances they are no longer available to food webs. A series of experiments was conducted to quantitatively examine this premise using 2 estuarine bivalves from San Francisco Bay, USA: the suspension feeder Potamocorbula amurensis and the facultative deposit feeder Macoma balthica. HA and FA, isolated from marine sediments, were bound as organic coatings to either hydrous ferric oxides (HFO) or silica particles. $\mathrm{Cd}$ and $\mathrm{Cr}$ (III) were adsorbed to the organic coatings or directly to uncoated HFO and silica particles. Pulse-chase laboratory feeding experiments using ${ }^{109} \mathrm{Cd}$ and ${ }^{5 i} \mathrm{Cr}(\mathrm{III})$ were then conducted to determine absorption efficiencies of $\mathrm{Cd}$ and $\mathrm{Cr}$ for individual specimens using each of the particle types. The results demonstrated that: (1) absorption of Cr(III) from all types of non-living particles was consistently low (< $11 \%)$. Ingested $\mathrm{Cd}$ showed greater bioavailability than $\mathrm{Cr}(\mathrm{III})$, perhaps due to differences in metal chemistry. (2) Bivalves absorbed $\mathrm{Cd}$ bound to uncoated HFO or silica particles (i.e. with no HA or FA present). (3) The presence of organic coatings on particles reduced Cd bioavailability compared with uncoated particles. (4) Both geochemical and biological conditions affected the food chain transfer of Cd. The data suggest that in marine systems inorganic and organic-coated particles are predominantly a sink for $\mathrm{Cr}$ in sediments. In the transfer of $\mathrm{Cd}$ to consumer animals, inorganic particles and humic substances can act as a link (although not a highly efficient one) under oxidized conditions.
\end{abstract}

KEY WORDS: Assimilation · Bioavailability $\cdot$ Clams $\cdot$ Fulvic acid $\cdot$ Humic acid $\cdot$ Metals

\section{INTRODUCTION}

Humic substances, such as humic acids (HA) and fulvic acids (FA), represent an operationally defined and abundant form of organic matter that is relatively refractory to both consumer animals and microorganisms (Mayer 1989). Humic substances originate from biochemical compounds, but are converted to structurally complex, biologically refractory materials by processes other than biochemical reactions (Mayer 1989). Humic and fulvic acids have considerable ion-

- Present address: Department of Environmental Sciences, School of Public Health, University of South Carolina, Columbia, South Carolina 29208, USA exchange capacities ( 4 to $14 \mathrm{meq}^{-1} \mathrm{C}$ ) which result primarily from ionized carboxyl and phenolic hydroxyl groups (Preston 1979). Both types of humic substances can bind metals by complexation or ion-exchange mechanisms (MacCarthy \& Suffet 1989). They are a sink for metals (Rashid 1985) and toxic organic compounds (Mantoura 1981, MacCarthy \& Jimenez 1985) in sediments. Studies of fulvic acid-Cr complexes, for example, showed that chemical bonding is strong and non-labile. In one study, up to $84 \%$ of the interstitial $\mathrm{Cr}(\mathrm{III})$ was found associated with fulvic-like organics (Douglas \& Quinn 1989). Mayer et al. (1983) showed that riverine colloids, which contain a high percentage of humic substances, are particularly important in chromium complexation as the colloids form flocs upon mixing with seawater. 
Humic materials are common in estuarine and nearshore marine sediments, comprising 10 to $68 \%$ of the total sedimentary organic carbon (Brown et al. 1972, Jones \& Jordan 1979). Aggregation of riverine particulates, colloidal materials, and dissolved humic materials occurs in estuaries with increasing ionic strength (i.e. salinity). Aggregation and co-precipitation with iron oxides result in the formation of complex, coated particulates (Sholkovitz et al. 1978, Mayer 1982, Luoma \& Davis 1983, Tipping 1986). Humification also may occur within estuarine sediments, and contribute to the accumulation of humic compounds on particle surfaces in sediments. Fulvic acids generally have a lower molecular weight than humic acids, and a higher O-content, higher carboxylic content and higher acidity (Francois 1990). Thus fulvic acids are the more water-soluble of the two. Ratios of HA to FA in estuarine and coastal marine sediments range from 0.4 to 3.4 (Brown et al. 1972, MacFarlane 1978).

Humic substances are ingested by animals that ingest particulate detritus and thus could represent a source of particulate metal exposure to such animals. Organic polymer coatings of bacterial origin can enhance metal bioavailability from particles. Harvey \& Luoma (1985a) showed that the bioavailability of particle-bound $\mathrm{Cd}$ and $\mathrm{Zn}$ to a deposit-feeding clam increased when particles were coated with bacterial exopolymer. It is not known, however, if humic-type polymer coatings enhance or reduce the bioavailability of metal from ingested particles.

Bivalves may be especially efficient at assimilating particle-bound metals (Luoma \& Jenne 1976, Amiard 1978, Harvey \& Luoma 1985b, Martoja et al, 1988), and thus could be sensitive to effects of humic coatings on metal bioavailability. Many bivalves possess a 2-phase digestive tract (Widdows et al. 1979). Ingested food particles are sorted in the stomach, then passed through a rapid 'intestinal' digestion. A fraction of the food is further processed by a slower, intensive, largely intracellular, 'glandular' digestion. Some metal forms are not assimilated during intestinal digestion but are available to the organism via glandular digestion (Decho \& Luoma 1991). Metals not available from sediments to species with simple digestive systems (van Klump et al. 1987) may be available to bivalves with systems capable of intensive digestion.

Recent advances have allowed quantitative estimation of metal bioavailability from ingestion (Fisher et al. 1991, Reinfelder \& Fisher 1991, Luoma et al. 1992) and separation of absorption efficiencies in the different phases of bivalve digestion (Decho \& Luoma 1991). These studies used pulse-chase techniques to determine absorption efficiency, a physiological constant that can be compared among species and among food types and can be used in models to predict bioaccumu- lation. In the present study we used the pulse-chase approach to determine if iron oxide and humic coatings on inorganic silica particles affected absorption efficiencies of $\mathrm{Cd}$ and $\mathrm{Cr}$ by 2 marine bivalves. Progressively layered coatings were added to silica particles to simulate complex sedimentary particulates. Digestive partitioning was followed to determine its effect on absorption efficiency.

\section{CHOICE OF SPECIES AND ELEMENTS}

The bivalves compared in this study were the facultative deposit feeder Macoma balthica and the suspension feeder Potamocorbula amurensis. The latter is a poorly known, active filter feeder that recently invaded San Francisco Bay, USA, from estuaries in east Asia (Nichols et al. 1990). These 2 species represent the 2 major feeding types common among bivalves. They also differ in digestive characteristics. Gut passage time in $P$. amurensis is $<1 \mathrm{~h}$, intestinal digestion is complete in ca $3 \mathrm{~h}$ and gut residence time is $24 \mathrm{~h}$ (Decho \& Luoma 1991). Gut passage time in $M$. balthica is 3 to $6 \mathrm{~h}$, intestinal digestion is complete in ca $24 \mathrm{~h}$ and total gut residence time is 72 to $96 \mathrm{~h}$.

Chromium was chosen for study because it is a common contaminant in estuaries. ${ }^{51} \mathrm{Cr}$ is also used as a tracer that is 'inert' to digestion in studies of carbon absorption efficiencies (Calow \& Fletcher 1972, Lopez \& Cheng 1983, Bricelj et al. 1984). Some forms of $\mathrm{Cr}$ are, indeed, not assimilated (Lopez et al. 1989), but others are. For example, when bound to bacteria, $\mathrm{Cr}$ (III) is efficiently assimilated ( $>85 \%$ ) in the digestive gland of Potamocorbula amurensis (Decho \& Luoma 1991). An understanding of $\mathrm{Cr}$ assimilation from different types of particles (including sedimentary particles where iron oxide and humic substance coatings are common) is essential to the future use of this element as an inert digestive tracer. It also will aid in understanding the fate of $\mathrm{Cr}$ in contaminated ecosystems.

Cadmium uptake by invertebrates has been widely studied, but conclusions differ about pathways of bioaccumulation. Sulfides in sediments reduce $\mathrm{Cd}$ bioavailability (DiToro et al. 1990), but the abundance of sulfides in the oxic environments experienced by most macrofauna is not well known (Luoma \& Carter 1993). Some authors suggest that $\mathrm{Cd}$ is principally available to benthos from interstitial waters (Swartz et al. 1985, DiToro et al. 1990). Field studies suggested that Cd uptake from solution can be important for deposit-feeding bivalves and polychaetes in English estuaries (Bryan \& Langston 1992) and bivalves in lakes from Quebec, Canada (Tessier et al. 1993). On the other hand $\mathrm{Cd}$ uptake from food by aquatic organisms has also been demonstrated (Sick \& Baptist 1979, 
Wikfors \& Ukeles 1982, Borchardt 1983, van Hattum et al. 1989, Timmermans et al. 1992). Most of the experimental studies have employed living food sources (Amiard 1992). Few studies have considered whether abiotic sources of bioavailable $\mathrm{Cd}$ occur in oxidized sediments. Harvey \& Luoma (1985a) showed little Cd uptake from iron oxide flocs, but detectable uptake from natural sedimentary particles, in studies with the deposit feeder Macoma balthica. Van Klump et al. (1987) found no detectable Cd uptake from sediments by oligochaetes.

\section{MATERIALS AND METHODS}

Seawater. All seawater (SW) used for experimental procedures was collected at the Long Marine Facility (Univ. California at Santa Cruz, USA). The SW used in isolations and adsorption experiments was initially filtered (Whatman GF/C), then cleaned by activated carbon sorption, followed by filtration ( $0.2 \mu \mathrm{m}$ Nuclepore) All the deionized water used in extractions and purifications was ultraclean high-resistance (i.e. $18 \mathrm{M} \Omega$ $\mathrm{cm}^{-1}$. All glassware used in extractions and isolations was acid-washed and rinsed in ultraclean water.

Isolation of humic and fulvic acids. Humic substances were extracted from fresh samples of sediment (ca $1 \mathrm{~g}$ each) collected from an intertidal mudflat on south San Francisco Bay (near Palo Alto). Sediments were added to $100 \mathrm{ml}$ of deoxygenated $0.5 \mathrm{M} \mathrm{NaOH}$ solution containing $1.0 \mathrm{~N} \mathrm{Na}_{4} \mathrm{P}_{2} \mathrm{O}_{7}$ and stirred for $24 \mathrm{~h}$ in a glove box under nitrogen atmosphere and subdued light.

MIBK procedure: The MIBK (methyl isobutyl ketone) procedure was used to separate humic acids (HA) from fulvic acids (FA) and humin material. The entire mixture from the $\mathrm{NaOH}$ extractions was transferred to a separatory funnel along with $75 \mathrm{ml}$ of MIBK and extracted according to the procedure of Rice \& MacCarthy (1989). The samples were acidified to $\mathrm{pH} 1$ with concentrated $\mathrm{HCl}$, then shaken vigorously and organic matter was allowed to partition between the organic and aqueous phases. The FA remains in the aqueous phase while HA and humin enter the MIBK phase as a suspension. Both the organic phase (containing the HA and huminj and the aqueous phase (containing the FA) were collected. The aqueous phase was re-extracted twice using the same procedure. The final aqueous phase contained the FA, and was adjusted to $\mathrm{pH} 7.0$ then rotoevaporated to remove any residual MIBK. The organic phase, derived from the initial MIBK extraction, contained most of the HA and humin. It was mixed with $100 \mathrm{ml}$ of $0.5 \mathrm{M} \mathrm{NaOH}$ in a separatory funnel, and shaken vigorously. The HA enters the aqueous alkaline phase while the humin remains in the organic phase. This procedure was repeated twice. The aqueous phase containing the HA was adjusted to $\mathrm{pH} 7.0$, then rotoevaporated.

XAD extractions: The separated HA and FA were purified on Amberlite XAD-8 resin (40 to 60 mesh) according the methods of Thurman \& Malcolm (1981). The resin, previously cleaned by sequential Soxhlet extractions, was packed using an $\mathrm{H}_{2} \mathrm{O}$-resin slurry into a $106 \mathrm{ml}$ column and rinsed with $3 \mathrm{l}$ of ultra-clean water. The column was successively cleaned 5 times with $0.1 \mathrm{M} \mathrm{NaOH}$ and $0.1 \mathrm{M} \mathrm{HCl}$, leaving the resin in an acid state prior to sample addition. Acidified samples ( $\mathrm{pH} \mathrm{2.0)}$ of HA and FA, diluted to $<25 \mathrm{mg}$ dissolved organic carbon (DOC) $l^{-1}$ (final concentration), were passed separately through the XAD columns at a flow rate of 4 to $5 \mathrm{ml} \mathrm{min} \mathrm{m}^{-1}$. The $\mathrm{HA}$ or FA was then eluted from the column using $0.1 \mathrm{~N} \mathrm{NaOH}$ (flow rate 1 to $2 \mathrm{ml} \mathrm{min}^{-1}$ ). The eluate (containing the $\mathrm{HA}$ or FA) was sent directly to a cation-exchange column containing AGMP-50 resin to desalt the HA and FA. The isolated $\mathrm{HA}$ and FA $(\mathrm{pH} \mathrm{7.0)}$ were then kept frozen $\left(-70^{\circ} \mathrm{C}\right)$ until use.

Preparation of food particles. Silica particles were coated with hydrous iron oxides and then either HA or FA to create distinct particles and better simulate the complex aggregations that characterize particles in natural, oxidized sediments

Hydrophilic 'Min-U-Sil' quartz silica particles (ca 10 to $30 \mu \mathrm{m}$ diameter), which possess the bulk geochemical properties of quartz, were used, though their surface properties may be dominated by amorphous silica. The particles were acid-washed then rinsed 3 times in ultra-clean water before radiolabeling. Absorption efficiencies from uncoated silica particles were used to examine the bioavailability of metals directly bound to this mineralogical substrate.

A second set of acid-washed silica particles were coated with hydrous ferric oxides (HFO) in the form of $\mathrm{Fe}(\mathrm{OH})_{3}$ (Edwards \& Benjamin 1989). The particles were placed in glass scintillation vials containing a solution of $\mathrm{FeNO}_{3}(4 \mathrm{M})$. The solution just covered the particles. The particle solution was dried at $100^{\circ} \mathrm{C}$ for 24 to $36 \mathrm{~h}$ to form the coatings. The coated particles were resuspended in ultraclean water and washed by repeated (i.e. 5 times) low speed $(1000 \times g)$ centrifugation to remove most colloidal HFO and nitric acid residues. The newly formed HFO particles were used in experiments within several days after preparation while the $\mathrm{HFO}$ remained in a relatively amorphous state, as determined by scanning electron microscopy. Others have shown that this approach results in silica particles completely covered with $\mathrm{HFO}$, containing $1 \pm 0.2 \times 10^{-2} \mathrm{~g} \mathrm{Fe} \mathrm{g}^{-1}$ sediment (Edwards \& Benjamin 1989) and 0.205 mole sites $\mathrm{mol}^{-1} \mathrm{Fe}$ (Dzomback \& Morel 1990). 
A third set of particles (silica and HFO-coated silica) were coated with either HA or FA. The binding of FA and HA to the silica and HFO particles was monitored spectrophotometrically. Known amounts of particles $(50 \mathrm{mg})$ were mixed with a HA or FA solution $(10 \mathrm{mg} \mathrm{C}$ $\mathrm{l}^{-1}$ final conc.) in teflon containers and gently shaken. Periodic subsamples $(1 \mathrm{ml})$ were removed at $2 \mathrm{~h}$ intervals (for $30 \mathrm{~h}$ ), and centrifuged to pellet the particles. The HA or FA remaining in the suspension was measured spectrophotometrically at 320 and $460 \mathrm{~nm}$. The $\mathrm{pH}$ of the suspensions was periodically monitored and maintained between 7.8 and 8.0 throughout the experimental period. Spectrophotometric measurements of the HA and FA were initially calibrated using independent measurements of total DOC (courtesy of Dr J. Kuwabara, U.S. Geological Survey). Humic substances, such as HA and FA, typically contain 4 to 14 meq $\mathrm{g}^{-1} \mathrm{C}$ of ion exchange sites (Preston 1979).

Binding of metals to particles. The metals, $\mathrm{Cr}$ (III) and $\mathrm{Cd}$, were adsorbed to the 6 different types of particles: uncoated silica, uncoated $\mathrm{HFO}$, humic-coated silica, fulvic-coated silica, humic-coated $\mathrm{HFO}$, and fulviccoated HFO. Metals were sorbed to the particles for $24 \mathrm{~h}$ at $\mathrm{pH} 7.8$ to 8.0 in precleaned SW ( $20 \%$ salinity) at $20^{\circ} \mathrm{C}$. Metal solutions, to which the particles were added, consisted of both radioisotope and carrier metal at a constant concentration $\left(\mathrm{CdCl}_{2}=4.4 \times 10^{-8} \mathrm{Mi} \mathrm{CrCl}_{2}\right.$ $\left.=1.9 \times 10^{-6} \mathrm{M}\right)$. 'High' and 'low' loadings were achieved by adjusting amounts of particulate in the metal solutions. For example, for 'low' Cd loadings, $500 \mathrm{mg}$ sediment were added to $50 \mathrm{ml}$ seawater containing $5 \mathrm{\mu g} \mathrm{l}^{-1} \mathrm{Cd}$ to yield a nominal concentration of $0.5 \mu \mathrm{g} \mathrm{Cd} \mathrm{g}^{-1}$ sediment (Tables $1 \& 2$ ). After incubations, the particles were washed in SW and centrifuged to remove unbound metal. Distribution coefficients $\left(K_{\mathrm{d}}\right)$ were calculated as the amount of metal bound divided by the amount of metal in solution at the end of the adsorption period, as determined by gamma counting:

$$
K_{\mathrm{d}}=\frac{\mu g \text { metal } \mathrm{g}^{-1} \text { solid }}{\mu \mathrm{g} \text { metal } \mathrm{ml}^{-1} \text { solution }}
$$

Gamma counting. The isotopes ${ }^{51} \mathrm{Cr}$ (half-life $27.8 \mathrm{~d}$ ) and ${ }^{109} \mathrm{Cd}$ (half-life $462.6 \mathrm{~d}$ ) were analyzed by gamma counting using a $\mathrm{NaI}$ crystal. Channel windows were set at 15 to $40 \mathrm{keV}$ for $\mathrm{Cd}$ and 240 to $400 \mathrm{keV}$ for Cr. Overlap of the Cr signal into the Cd channel was corrected using standards. Corrections for self-absorption of the Cd gamma signal by the bivalve shell were also employed for interpretations of whole-animal data.

Feeding experiments. Both species of bivalve were collected from a mudflat in the Carquinez strait of San Francisco Bay (Station \#M1 in Johns et al. 1988). Specimens were held in the laboratory at constant temperature $\left(10 \pm 2^{\circ} \mathrm{C}\right)$ and salinity $(20 \%)$ in microcosms containing sediments from the collection site. Each day food material, consisting of a suspension of fine sediment flocculent material, was added to the chambers. Experiments were commenced within $2 \mathrm{~d}$ after collection. The clams used in the experiments were adults of a similar size within a species. Macoma balthica ranged in shell diameter from approximately 1.0 to $1.7 \mathrm{~cm}$. Potamocorbula amurensis ranged from 0.75 to $1.5 \mathrm{~cm}$. For the experiments, 8 to 12 individuals were first placed in a microcosm containing a suspension of unlabeled food material and allowed to acclimate for several hours. A suspension of experimental particles labeled with both ${ }^{51} \mathrm{Cr}$ and ${ }^{109} \mathrm{Cd}$ was then added. For

Table 1. Adsorbed cadmium concentrations (i.e. loadings) and geochemical characterization of particles used in feeding experiments. H: high metal loading; L: low metal loading; na: not applicable. Distribution coefficient is defined as $\mu \mathrm{g} \mathrm{g}^{-1}$ of metal bound divided by $\mu \mathrm{g} \mathrm{ml}^{-1}$ of metal in solution at the end of the adsorption experiment. TOC: total organic carbon; HFO: hydrous ferric oxides

\begin{tabular}{|c|c|c|c|c|c|}
\hline $\begin{array}{l}\text { Labeled } \\
\text { sediment } \\
\text { particles }\end{array}$ & $\begin{array}{c}\text { Particle } \\
\text { conc. } \\
\text { (g) }\end{array}$ & $\begin{array}{c}\text { Metal } \\
\text { adsorbed } \\
\text { (proportion) }\end{array}$ & $\begin{array}{l}\text { Metal loading } \\
\text { in sediment } \\
\left(\mu g^{-1} \text { dry wt) }\right.\end{array}$ & $\begin{array}{l}\text { Distribution } \\
\text { coefficient }\end{array}$ & $\begin{array}{c}\text { Particulate } \\
\text { TOC } \\
(\%)\end{array}$ \\
\hline HFO-uncoated L & 0.5 & 0.44 & 0.2 & 79 & na \\
\hline $\begin{array}{l}\text { HFO-humic H } \\
\text { HFO-humic L }\end{array}$ & $\begin{array}{l}0.005 \\
0.5\end{array}$ & $\begin{array}{l}0.41 \\
0.81\end{array}$ & $\begin{array}{r}20.5 \\
0.4\end{array}$ & $\begin{array}{r}6949 \\
426\end{array}$ & $\begin{array}{l}0.241 \\
0.241\end{array}$ \\
\hline $\begin{array}{l}\text { HFO-fulvic H } \\
\text { HFO-fulvic L }\end{array}$ & $\begin{array}{l}0.005 \\
0.5\end{array}$ & $\begin{array}{l}0.64 \\
0.84\end{array}$ & $\begin{array}{r}32.0 \\
0.4\end{array}$ & $\begin{array}{r}17778 \\
525\end{array}$ & $\begin{array}{l}0.0019 \\
0.0019\end{array}$ \\
\hline Si-uncoated L & 0.5 & 0.78 & 0.4 & 355 & na \\
\hline $\begin{array}{l}\text { Si-humic H } \\
\text { Si-humic L }\end{array}$ & $\begin{array}{l}0.005 \\
0.5\end{array}$ & $\begin{array}{l}0.26 \\
0.33\end{array}$ & $\begin{array}{r}13.0 \\
0.2\end{array}$ & $\begin{array}{r}3514 \\
49\end{array}$ & $\begin{array}{l}0.173 \\
0.173\end{array}$ \\
\hline $\begin{array}{l}\text { Si-fulvic H } \\
\text { Si-fulvic L }\end{array}$ & $\begin{array}{l}0.005 \\
0.5\end{array}$ & $\begin{array}{l}0.34 \\
0.52\end{array}$ & $\begin{array}{r}17.0 \\
0.3\end{array}$ & $\begin{array}{r}5152 \\
108\end{array}$ & $\begin{array}{l}0.0026 \\
0.0026\end{array}$ \\
\hline
\end{tabular}


Table 2. Adsorbed chromium(III) concentrations (i.e. loadings) and geochemical characterization of particles used in feeding experiments. $\mathrm{H}$ : high metal loading; $\mathrm{L}$ : low metal loading; na: not applicable. Distribution coefficient is defined as $\mu \mathrm{g} \mathrm{g}^{-1}$ of

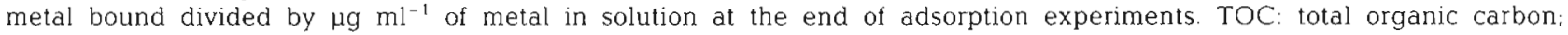
HFO: hydrous ferric oxides

\begin{tabular}{|c|c|c|c|c|c|}
\hline $\begin{array}{l}\text { Labeled } \\
\text { sediment } \\
\text { particles }\end{array}$ & $\begin{array}{c}\text { Particle } \\
\text { conc. } \\
\text { (g) }\end{array}$ & $\begin{array}{c}\text { Metal } \\
\text { adsorbed } \\
\text { (proportion) }\end{array}$ & $\begin{array}{l}\text { Metal loading } \\
\text { in sediment } \\
\left(\mu g g^{-1} \mathrm{dry} w \mathrm{t}\right)\end{array}$ & $\begin{array}{c}\text { Distribution } \\
\text { coefficient }\end{array}$ & $\begin{array}{c}\text { Particulate } \\
\text { TOC } \\
(\%)\end{array}$ \\
\hline HFO-uncoated L & 0.5 & 0.72 & 7.2 & 257 & na \\
\hline $\begin{array}{l}\text { HFO-humic H } \\
\text { HFO-humic L }\end{array}$ & $\begin{array}{l}0.005 \\
0.5\end{array}$ & $\begin{array}{l}0.33 \\
0.8\end{array}$ & $\begin{array}{r}330.0 \\
8.0\end{array}$ & $\begin{array}{r}4925 \\
400\end{array}$ & $\begin{array}{l}0.241 \\
0.241\end{array}$ \\
\hline $\begin{array}{l}\text { HFO-fulvic H } \\
\text { HFO-fulvic L }\end{array}$ & $\begin{array}{l}0.005 \\
0.5\end{array}$ & $\begin{array}{l}0.23 \\
0.69\end{array}$ & $\begin{array}{r}230.0 \\
6.9\end{array}$ & $\begin{array}{r}2987 \\
223\end{array}$ & $\begin{array}{l}0.0019 \\
0.0019\end{array}$ \\
\hline Si-uncoated I & 0.5 & 0.75 & 7.5 & 300 & na \\
\hline $\begin{array}{l}\text { Si-humic H } \\
\text { Si-humic L }\end{array}$ & $\begin{array}{l}0.005 \\
0.5\end{array}$ & $\begin{array}{l}0.25 \\
0.51\end{array}$ & $\begin{array}{r}250.0 \\
5.1\end{array}$ & $\begin{array}{r}3333 \\
104\end{array}$ & $\begin{array}{l}0.173 \\
0.173\end{array}$ \\
\hline $\begin{array}{l}\text { Si-fulvic H } \\
\text { Si-fulvic L }\end{array}$ & $\begin{array}{l}0.005 \\
0.5\end{array}$ & $\begin{array}{l}0.11 \\
0.35\end{array}$ & $\begin{array}{r}110.0 \\
3.5\end{array}$ & $\begin{array}{r}1236 \\
54\end{array}$ & $\begin{array}{l}0.0026 \\
0.0026\end{array}$ \\
\hline
\end{tabular}

M. balthica the labeled-pulse feed period was 2 to 2.5 h. For $P$. amurensis the labeled pulse was 15 to 20 min (Decho \& Luoma 1991). The short labeled-pulse approach minimized exposure to solute metal and allowed direct determination of metal influx from assimilation.

At the end of the labeled-pulse feed period the clams were removed, rinsed in SW, and placed in scintillation vials containing $10 \mathrm{ml} \mathrm{SW}$. The living clams were analyzed by gamma counting to determine the amount of ingested labeled-food particles $\left(T_{0}\right)$. The clams were then placed in 'cold-feed' microcosms containing unlabeled food material. This allowed them to continue feeding in the presence of natural food resources while egestion of labeled feces occurred. During the coldfeed period fecal pellets egested by the clams were collected periodically, placed in scintillation vials and analyzed by gamma counting. Pseudofeces were separated from feces (Decho \& Luoma 1991). SW and food suspensions in the cold-feed microcosms were changed approximately every 8 to $12 \mathrm{~h}$ to maintain ample food concentrations and to reduce the accumulation of solute radionuclide or toxic byproducts by the clams.

When egestion was complete ( $72 \mathrm{~h}$ for Macoma balthica and $24 \mathrm{~h}$ for Potamocorbula amurensis; Decho \& Luoma 1991), clams were removed from the microcosms, thoroughly rinsed, gamma counted and then frozen $\left(-70^{\circ} \mathrm{C}\right)$. Soft tissues were later dissected from the shell while frozen. Shell and soft tissues were placed separately in scintillation vials and then analyzed.

A mass-balance approach was chosen to calculate overall absorption efficiency. A typical data set for each clam is shown in Tables $3 \& 4$. The absorption efficiency $(\% \mathrm{AE})$ was calculated as:

$\% \mathrm{AE}=\frac{\mathrm{dpm} \text { tissue at } 24(72) \mathrm{h}}{\left(\mathrm{dpm} \sum \text { feces }\right)+[\mathrm{dpm} \text { tissue at } 24(72) \mathrm{h}]} \times 100$

In preliminary experiments, Macoma balthica were exposed to the water from an exposure pulse. Uptake was less than $5 \%$ of the ingested activity; thus dissolved sources did not contribute to the $T_{0}$ value. A high concentration of $\mathrm{Cd}$ and $\mathrm{Cr}$ on the shells (Tables 3 \& 4) raised the possibility of bias from uptake of dissolved $\mathrm{Cd}$ and $\mathrm{Cr}$ during the cold-feeding incubations. Other evidence suggested that bias also was small. Chromium was strongly particle-associated and differences in the mass balance between $T_{0}$ whole-animal Cr counts and the sum of final (tissue + shell + feces) counts were small (generally $<4 \%$ ). Thus very little $\mathrm{Cr}$ was lost to solution during egestion; not enough to affect the absorption efficiency estimates. Cadmium could desorb more readily from feces. Initial $\left(T_{0}\right)$ whole-animal activities differed from the sum of final (tissue + shell + feces) activities by 10 to $20 \%$ with no detectable trends attributable to particle type. Thus some $\mathrm{Cd}$ could have entered the solution during the egestion period. Because the chamber waters were changed frequently, preventing build-up of ${ }^{109} \mathrm{Cd}$, effects on absorption efficiency estimates would however have been small. Luoma et al. (1992) showed comparative results for different approaches to calculating AE with pulse-chase methodology.

A previous study (Decho \& Luoma 1991) has shown that a pulse of radiolabeled food material will be 
Table 3. Potamocorbula amurensis. Complete data set for clams exposd to ${ }^{109} \mathrm{Cd}$ and ${ }^{51} \mathrm{Cr}$-labeled $\mathrm{HFO}$ (low) (uncoated) particles, a typical experiment. \% AE: percentage absorption efficiency calculated by mass balance

\begin{tabular}{|c|c|c|c|c|c|}
\hline $\begin{array}{l}\text { Specimen } \\
\text { no. }\end{array}$ & $\begin{array}{c}\text { Sum feces } \\
\text { (dpm) } \\
\text { A }\end{array}$ & $\begin{array}{c}\text { Tissue } \\
\text { (dpm } 24 \mathrm{~h}) \\
\mathrm{B}\end{array}$ & $\begin{array}{c}\text { Shell } \\
(\mathrm{dpm} 24 \mathrm{~h}) \\
\mathrm{C}\end{array}$ & $\begin{array}{c}\% A E \\
(B / A+B) \\
D\end{array}$ & $\begin{array}{c}\text { Whole clam } \\
\begin{array}{c}\left(T_{0} \mathrm{dpm}\right) \\
\mathrm{E}\end{array}\end{array}$ \\
\hline \multicolumn{6}{|l|}{ Cadmium } \\
\hline 1 & 75796 & 15744 & 16561 & 17 & 126267 \\
\hline 2 & 54551 & 18604 & 13175 & 25 & 92329 \\
\hline 3 & 93943 & 56870 & 29228 & 38 & 163497 \\
\hline 4 & 207621 & 45238 & 37866 & 18 & 231491 \\
\hline 5 & 63159 & 65210 & 13418 & 51 & 149262 \\
\hline 6 & 106564 & 67133 & 40481 & 39 & 209767 \\
\hline 7 & 196914 & 147865 & 8850 & 43 & 314447 \\
\hline $\bar{x} \pm \mathrm{SD}$ & $114078 \pm 62816$ & $59523 \pm 44152$ & $22797 \pm 12878$ & $34 \pm 13$ & $183866 \pm 74498$ \\
\hline \multicolumn{6}{|l|}{ Chromium } \\
\hline 1 & 100103 & 282 & 4194 & 0.3 & 115179 \\
\hline 2 & 67188 & 220 & 2189 & 0.3 & 83144 \\
\hline 3 & 180718 & 960 & 5355 & 0.5 & 196355 \\
\hline 4 & 255044 & 647 & 6442 & 0.3 & 259748 \\
\hline 5 & 106949 & 2307 & 4059 & 2.1 & 147840 \\
\hline 6 & 136288 & 539 & 23861 & 0.4 & 185364 \\
\hline 7 & 315700 & 2820 & 6769 & 0.9 & 344947 \\
\hline $\bar{x} \pm \mathrm{SD}$ & $165999 \pm 90398$ & $1111 \pm 1032$ & $7553 \pm 7358$ & $0.7 \pm 0.6$ & $190368 \pm 89189$ \\
\hline
\end{tabular}

Table 4. Macoma balthica. Complete data set for clams exposd to ${ }^{109} \mathrm{Cd}$ and ${ }^{51} \mathrm{Cr}$-labeled HFO (low) (uncoated) particles, a typical experiment. \% AE: percentage absorption efficiency calculated by mass balance

\begin{tabular}{|c|c|c|c|c|c|}
\hline $\begin{array}{l}\text { Specimen } \\
\text { no. }\end{array}$ & $\begin{array}{c}\text { Sum feces } \\
\text { (dpm) } \\
\text { A }\end{array}$ & $\begin{array}{c}\text { Tissue } \\
\text { (dpm } 72 \mathrm{~h}) \\
\mathrm{B}\end{array}$ & $\begin{array}{c}\text { Shell } \\
\text { (dpm } 72 \text { h) } \\
\text { C }\end{array}$ & $\begin{array}{c}\% A E \\
(B / A+B) \\
D\end{array}$ & $\begin{array}{c}\text { Whole clam } \\
\qquad \begin{array}{c}\left(T_{0} \mathrm{dpm}\right) \\
\text { E }\end{array}\end{array}$ \\
\hline \multicolumn{6}{|l|}{ Cadmium } \\
\hline 1 & 18651 & 2131 & 4191 & 10 & 38545 \\
\hline 2 & 25406 & 15143 & 9002 & 37 & 52360 \\
\hline 3 & 52893 & 60096 & 11248 & 53 & 101742 \\
\hline 4 & 28163 & 10930 & 6967 & 28 & 62888 \\
\hline 5 & 32350 & 30309 & 8914 & 48 & 61348 \\
\hline 6 & 32867 & 16987 & 5065 & 34 & 49375 \\
\hline $\bar{x} \pm \mathrm{SD}$ & $31721 \pm 11605$ & $22599 \pm 20531$ & $7565 \pm 2662$ & $35 \pm 15$ & $61043 \pm 21806$ \\
\hline \multicolumn{6}{|l|}{ Chromium } \\
\hline 1 & 23902 & 510 & 623 & 2.1 & 60717 \\
\hline 2 & 81.432 & 443 & 771 & 0.5 & 77114 \\
\hline 3 & 113303 & 2547 & 982 & 2.2 & 116528 \\
\hline 4 & 52583 & 1587 & 1480 & 2.9 & 83029 \\
\hline 5 & 86698 & 1066 & 1015 & 1.2 & 86504 \\
\hline 6 & 69294 & 1353 & 1503 & 1.9 & 82046 \\
\hline $\bar{x} \pm \mathrm{SD}$ & $71202 \pm 30675$ & $1251 \pm 779$ & $1062 \pm 361$ & $1.8 \pm 0.8$ & $84323 \pm 18209$ \\
\hline
\end{tabular}

egested in 2 phases if food concentrations are kept low, and that egestion of ${ }^{51} \mathrm{Cr}$ can be used to quantify this digestive partitioning. ${ }^{51} \mathrm{Cr}$ is not taken up during the first, intestinal phase of digestion (Decho \& Luoma 1991). Therefore the percentage of food processed by intestinal digestion was determined from: $\begin{aligned} & \% \text { food processed by } \\ & \text { intestinal digestion }\end{aligned}=\frac{{ }^{51} \mathrm{C}_{\text {intestinal feces }}}{{ }^{51} \mathrm{Cr}_{\Sigma \text { (feces }+ \text { tissues) }}} \times 100$

where ${ }^{51} \mathrm{Cr}_{\text {intestinal feces }}$ is the sum of feces released before 3 h (Potamocorbula amurensis) or 24 h (Macoma balthica). The \% AE of Cd absorbed from food material 
processed by the intestinal digestion pathway alone was calculated as:

$$
\% A E_{\text {intestinal }}=\frac{(\mathrm{Cd} / \mathrm{Cr})_{\text {intestinal feces }}}{(\mathrm{Cd} / \mathrm{Cr})_{\text {lotal }}} \times 100
$$

where $(\mathrm{Cd} / \mathrm{Cr})_{\text {lotal }}$ was the ratio of $\mathrm{Cd} / \mathrm{Cr}$ in the sum of feces and tissues.

Statistical analyses. The \% AE data were normalized using arcsine transformations, then analyzed by a split-plot ANOVA for an unbalanced design with hierarchical decomposition (Sokal \& Rohlf 1981). The amounts of food processed by the digestive gland were plotted versus \% AE, and analyzed using linear regression (Steele \& Torrie 1980). All data transformations and analyses were conducted using the SYSTAT statistical analysis system (Wilkinson 1987).

\section{RESULTS}

\section{Humic substance coatings on particles}

Spectrophotometric analyses of the loss of FA and HA from solution to silica and HFO particles indicated a slow binding to particles (Fig. 1). Maximal binding was abserved after approximately $22 \mathrm{~h}$ incubation (pH 7.8 to $8.0,20 \%$ salinity). Approximately 20 to $25 \%$ of the HA were sorbed onto both silica and HFO particles. FA demonstrated a considerably lower affinity than HA for either particle type. Less than $0.25 \%$ of the added FA became associated with any of the particle types after $22 \mathrm{~h}$ under the experimental conditions. As a result, total organic carbon on the FA-coated particles was considerably lower than on HA-coated particles (Tables $1 \& 2$ ) and metal concentrations per mg $C$ were highest on the FA-coated particles.

\section{Binding of metals to particles}

As expected, a higher adsorbed concentration (i.e. loading) of $\mathrm{Cd}$ and $\mathrm{Cr}$ was achieved on particles when $5 \mathrm{mg}$ particles were added to the $50 \mathrm{ml}$ of labeled solu-

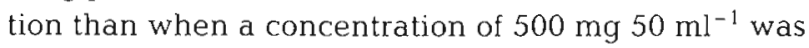
used. Proportionate sorption was also greater where particle concentrations were higher. The particulates with lower loadings of metal were typical of pristine or slightly contaminated sediments $\left(3\right.$ to $8 \mu \mathrm{g} \mathrm{Cr} \mathrm{g}{ }^{-1} ; 0.2$ to $0.4 \mu \mathrm{g} \mathrm{Cd} \mathrm{g}^{-1}$ ). The particulates with higher loadings (Tables $1 \& 2$ ) were typical of contaminated sediments, but were not beyond the range found in contaminated systems (Luoma 1990, Sadiq 1992).

The sorption of $\mathrm{Cd}$ to particles was influenced by the type of particle and the type of particle coating

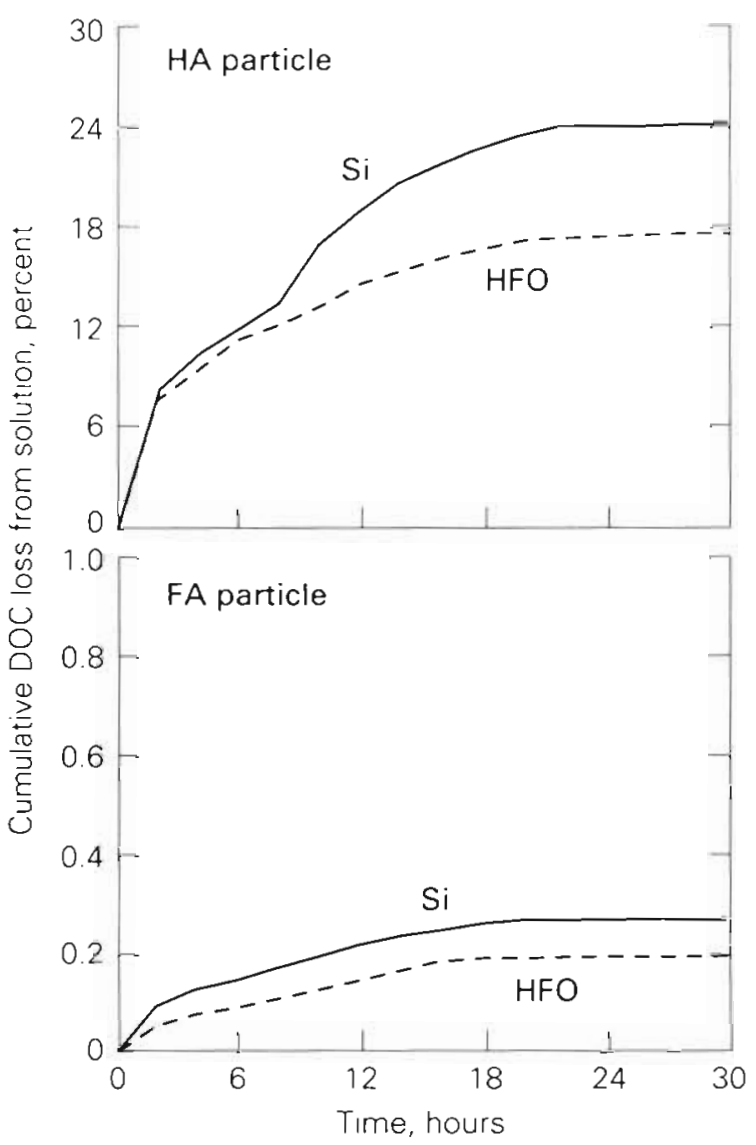

Fig. 1. The binding of humic substances, humic (HA) and fulvic acids (FA), to silica ( $\mathrm{Si}$ ) and hydrous ferric oxide (HFO) particles as a function of time

(Tables 1 \& 2). More Cd sorbed to uncoated Si than to uncoated HFO. Organic coatings reduced Cd sorption to $\mathrm{Si}$, while organic coatings enhanced $\mathrm{Cd}$ sorption to HFO, when similar conditions were compared (high particle concentrations, low metal concentrations). In contrast, $\mathrm{Cr}$ sorbed similarly to uncoated $\mathrm{Si}$ and uncoated HFO. Organic coating reduced $\mathrm{Cr}$ sorption to Si. Organic coating had no detectable effect on $\mathrm{Cr}$ sorption to HFO, under comparable conditions. Differences in the type of organic coating (HA vs FA) did not greatly affect the \% metal sorbed, total metal loadings, or the distribution coefficients (Tables 1 \& 2).

In earlier studies, nitrogen-gas adsorption surface areas determined on the same type of silica particles used here were $1 \pm 0.5 \mathrm{~m}^{2} \mathrm{~g}^{-1}$ using BET analysis (D. Kent pers. comm.). This represents $2.0 \times 10^{-7}$ mole sites $0.5 \mathrm{~g}^{-1}$ sediment. The calculated number of mole sites for uncoated HFO particles was $9.2 \times 10^{-7}$ sites $0.5 \mathrm{~g}^{-1}$ sediment. HA and FA typically contain 4 to $14 \mathrm{meq}$ $\mathrm{g}^{-1} \mathrm{C}$ of ion exchange sites (Preston 1979) which converts to 5 to $17.5 \times 10^{-5} \mathrm{meq} F A$ sites $0.5 \mathrm{~g}^{-1}$ sediment 
Table 5. Potamocorbula amurensis and Macoma balthica. Results of feeding experiments examining metal [Cd and $\mathrm{Cr}(\mathrm{III})]$ absorption by the clams fed different types of food particles. Values are mean percentage $( \pm \mathrm{SE}) . \% \mathrm{AE}$ irtestue $\mathrm{Cd}$ : \% $\mathrm{AE}$ of $\mathrm{Cd}$ absorbed from food material processed by the intestinal digestion pathway alone. HFO: hydrous ferric oxides; nd: not determined

\begin{tabular}{|c|c|c|c|c|c|c|c|c|}
\hline \multirow[t]{3}{*}{ Food particles } & \multicolumn{4}{|c|}{ Absorption efficiency } & \multirow{2}{*}{\multicolumn{2}{|c|}{$\begin{array}{l}\% \text { food processed by } \\
\text { glandular digestion }\end{array}$}} & \multirow{2}{*}{\multicolumn{2}{|c|}{$\% \mathrm{AE}_{\text {intestinal }} \mathrm{Cd}$}} \\
\hline & \multicolumn{2}{|c|}{$\mathrm{Cd}$} & \multicolumn{2}{|c|}{$\operatorname{Cr}(\mathrm{III})$} & & & & \\
\hline & P. amurensis & M. balthica & P. amurensis & M. balthica & P. amurensis & M. balthica & P. amurensis & M. balthica \\
\hline \multicolumn{9}{|c|}{ HFO-high (metal) } \\
\hline Uncoated & $35 \pm 6$ & nd & nd & nd & nd & nd & nd & nd \\
\hline Humic acid & $41 \pm 5$ & $25 \pm 9$ & $3 \pm 1$ & $3 \pm 1$ & $18 \pm 8$ & $37 \pm 29$ & 39 & 33 \\
\hline Fulvic acid & $42 \pm 7$ & $22 \pm 4$ & $4 \pm 1$ & $2 \pm 1$ & $28 \pm 15$ & $19 \pm 20$ & 37 & 30 \\
\hline \multicolumn{9}{|c|}{ HFO-low (metal) } \\
\hline Uncoated & $33 \pm 12$ & $35 \pm 15$ & $1 \pm 1$ & $2 \pm 1$ & $80 \pm 16$ & $51 \pm 32$ & 43 & 35 \\
\hline Humic acid & $12 \pm 1$ & $18 \pm 6$ & $6 \pm 1$ & $3 \pm 4$ & $44 \pm 18$ & $28 \pm 23$ & 12 & 23 \\
\hline Fulvic acid & $9 \pm 2$ & $16 \pm 4$ & $5 \pm 1$ & $2 \pm 1$ & $40 \pm 20$ & $10 \pm 5$ & 1 & 32 \\
\hline \multicolumn{9}{|l|}{ Si-high (metal) } \\
\hline Uncoated & $35 \pm 2$ & nd & $4 \pm 1$ & nd & $77 \pm 20$ & nd & nd & nd \\
\hline Humic acid & $12 \pm 1$ & $38 \pm 11$ & $6 \pm 1$ & $9 \pm 2$ & $51 \pm 19$ & $35 \pm 15$ & 9 & 42 \\
\hline Fulvic acid & $9 \pm 1$ & $17 \pm 3$ & $4 \pm 1$ & $4 \pm 1$ & $30 \pm 21$ & $15 \pm 10$ & 6 & 24 \\
\hline \multicolumn{9}{|l|}{ Si-low (metal) } \\
\hline Uncoated & $56 \pm 5$ & $9 \pm 6$ & $11 \pm 3$ & $3 \pm 1$ & $81 \pm 10$ & $47 \pm 22$ & nd & nd \\
\hline Humic acid & $16 \pm 3$ & $17 \pm 2$ & $8 \pm 2$ & $8 \pm 2$ & $63 \pm 9$ & $32 \pm 10$ & nd & 4 \\
\hline Fulvic acid & nd & $16 \pm 2$ & nd & $8 \pm 2$ & nd & $36 \pm 17$ & nd & 4 \\
\hline
\end{tabular}

and 4 to $14 \times 10^{-3}$ meq HA sites $0.5 \mathrm{~g}^{-1}$ sediment. Therefore, even at high metal loadings, saturation of ligands was not likely.

\section{Absorption efficiencies}

Detectable absorption of both $\mathrm{Cd}$ and $\mathrm{Cr}$ by both bivalves was observed when the clams ingested the different types of particles investigated in this study. Mean absorption efficiencies of $\mathrm{Cd}$ varied from 9 to $56 \%$. Absorption of $\mathrm{Cr}$ was consistently less than $11 \%$

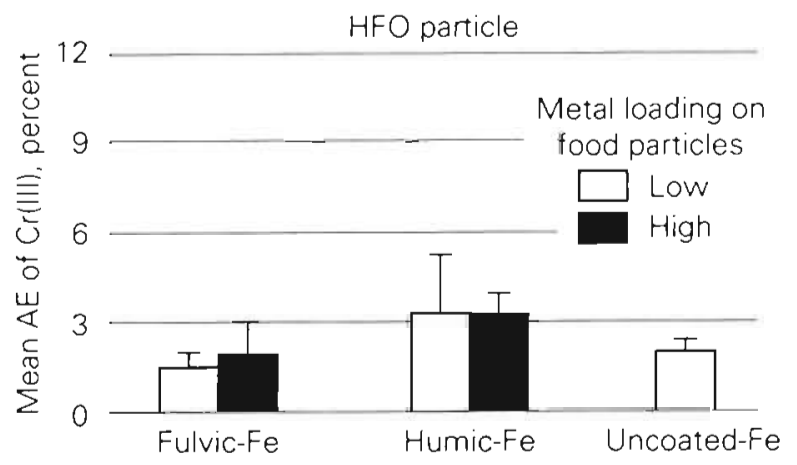

Fig. 2. Macoma balthica. Mean percent absorption efficiency (\% AE) of $\mathrm{Cr}$ in bivalve feeding experiments. Vertical bars represent $1 \mathrm{SD}$ from these non-living materials. Results from replicate experiments using the same type of particle were not as variable as differences between particle types. For example, when Potamocorbula amurensis was fed ${ }^{109} \mathrm{Cd}$-labeled $\mathrm{HFO}$ in 3 separate experiments, mean absorption efficiencies were $33 \pm 12,35 \pm 6$, and $44 \pm$ $2 \%$. In earlier studies, $P$. amurensis was fed ${ }^{51} \mathrm{Cr}$ labeled bacteria in 3 different experiments. Absorption efficiencies ranged from 85 to $95 \%$ (Decho \& Luoma 1991, unpubl. results). A complex mixture of processes appeared to cause the observed differences in absorption efficiency among treatments. These included: (1) metal-specific effects, (2) effects of different coatings, (3) metal loadings, (4) digestive processing and (5) species-specific effects.

\section{Metal-specific effects}

Absorption efficiencies of Cd were significantly ( $\mathrm{p}<$ 0.001 ) different than absorption efficiencies of $\mathrm{Cr}$ in most experiments, with both clams. With 1 exception, $\mathrm{Cd}$ was absorbed with a higher efficiency from all types of particles than was $\mathrm{Cr}$ (Table 5, Figs. 2 \& 3). For example, $\mathrm{Cd}$ was biologically available to both clams when bound to $\mathrm{HFO}$ or Si surfaces. Absorption efficiencies from $\mathrm{HFO}$, the substrate of most relevance in nature, were $33 \%$ or greater (Table 5). In contrast, absorption of $\mathrm{Cr}$ from uncoated particles was consistently low $(<4 \%$ with 1 exception). 
a

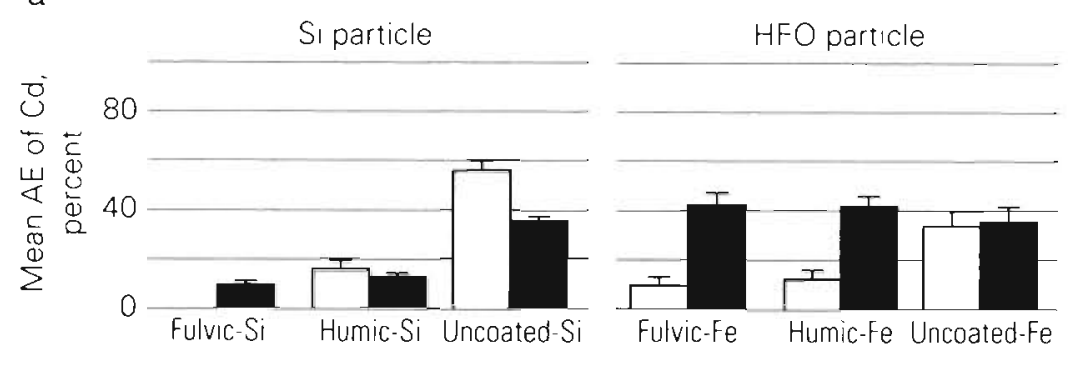

$b$

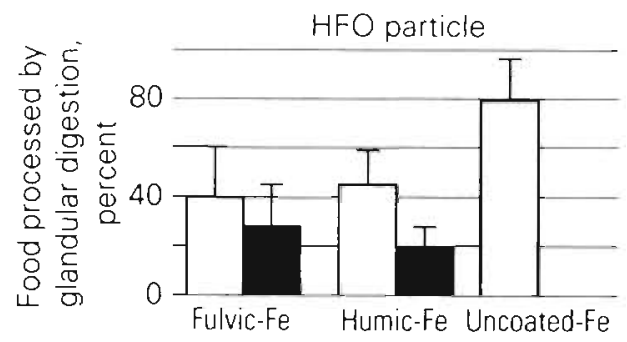

Metal loading on food particles

Fig. 3. Potamocorbula amurensis. (a) Mean percent absorption efficiency (\% AE) of $\mathrm{Cd}$ and (b) mean percent ingested food processed by glandular digestion in bivalve feeding experiments. Vertical bars represent $1 \mathrm{SD}$

Effect of organic coating

Organic coatings affected Cd bioavailability (Fig. 3). Over all experiments, absorption efficiencies for $\mathrm{Cd}$ ranged from 9 to $42 \%$ for organic-coated particles. The lowest AEs were observed when Potamocorbula amurensis ingested humic-coated particles with low

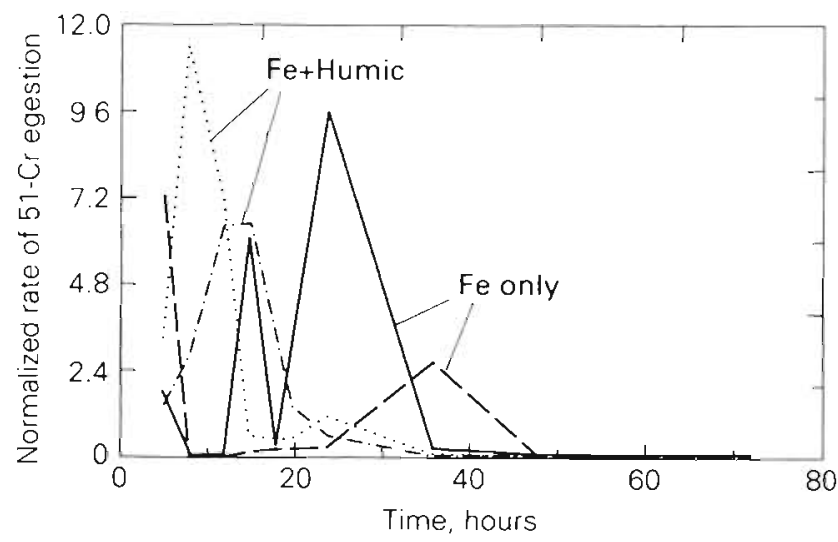

Fig. 4. Macoma balthica. Comparison of egestion rate of ${ }^{51} \mathrm{Cr}$ between organically coated particles and particles coated only with hydrous ferric oxide (HFO) in 4 individual bivalves. Data show $\mathrm{cpm} \mathrm{h}^{-1}$ egested, as determined from analysis of the feces of $M$. balthica at different time intervals during the egestion period. The rate is normalized to the average rate for each experiment in order to scale the experiments similarly $\square$ Low

$\square$ High

Cd loadings (Table 5, Fig. 3). Absorption efficiency from humic substances with low loadings of $\mathrm{Cd}$ were significantly less that AE from $\mathrm{HFO}$ or $\mathrm{Si}$ particles. Similar results were observed in Macoma balthica for humic coated-HFO particles (Table 5). Absorption of $\mathrm{Cd}$ from $\mathrm{Si}$ by $M$. balthica remained low ( 9 to $17 \%$ ) whether or not this type of particle was coated with organic material. The type of organic coating did not influence these results. In both species, AE from particles coated with FA was not significantly ( $p=0.170$ ) different than $\mathrm{AE}$ from HA-coated particles. Organic coatings either had no effect or slightly enhanced the consistently low Cr absorption efficiency.

\section{Metal loadings on particles}

The concentration of $\mathrm{Cd}$ on the particles appeared to affect absorption efficiency in Potamocorbula amurensis from the organically coated HFO particles (Fig. 3b). Significantly higher $(p=0.021)$ AE were observed when Cd loadings were high than when they were low for both HA- and FA-coated iron oxides. Intestinal AE was also higher at high $\mathrm{Cd}$ loadings than at low loadings. This suggested $\mathrm{Cd}$ was easily desorbed by digestive processes when concentrations were high. The concentration effect was less evident in Macoma balthica than in $P$. amurensis, and was not observed for $\mathrm{Cr}$.

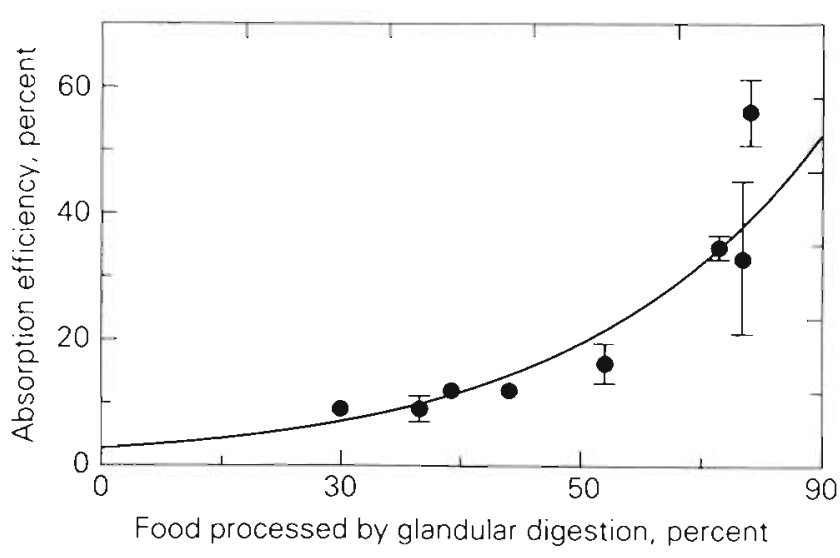

Fig. 5. Potamocorbula amurensis. Relationship between absorption efficiency of $\mathrm{Cd}$ and the proportion of ingested particles processed by glandular digestion. Each point represents the mean from each experiment. Vertical bars represent $1 \mathrm{SD}$ 


\section{Digestive processing}

Differences in the digestive processing of organiccoated and uncoated particles appeared to explain $\mathrm{Cd}$ absorption by Potamocorbula amurensis. Uncoated Si and HFO particles were retained longer during digestion than were organic-coated particles (Figs. 3b \& 4). Absorption of $\mathrm{Cd}$ increased exponentially as the proportion of particles subjected to prolonged digestion increased (Fig. 5). Differences in digestive processing, however, did not explain the enhancement of AE at high concentrations of $\mathrm{Cd}$. In fact, high concentrations of $\mathrm{Cd}$ appeared to coincide with less retention of food in the digestion gland in many experiments. Within experiments, absorption efficiency by individual animals increased however as a larger proportion of particles were processed by glandular digestion (Fig. 6).

The more intensive digestion of uncoated particles did not enhance $\mathrm{Cr}$ absorption efficiency as much as it did $\mathrm{Cd}$. Digestive partitioning affected $\mathrm{Cr}$ absorption only for certain particle types. Increased $\mathrm{Cr}-\mathrm{AE}$ in individual animals occurred when an increased proportion of HFO (organic-coated) was passed to the digestive gland of Potamocorbula amurensis $\left(\mathrm{r}^{2}=0.66, \mathrm{p}<0.001\right)$ and Macoma balthica $\left(\mathrm{r}^{2}=0.26, \mathrm{p}<0.01\right)$. However, the absorption efficiency of $\mathrm{Cr}$ was low no matter what the proportion of the particles retained in the digestive gland.

\section{Species-specific differences}

Macoma balthica retained a lower proportion of ingested particles for intensive digestion than did Potamocorbula amurensis in almost all experiments (Table 5). The maximum proportion of particles processed by the digestive gland in any experiment by $M$. balthica was $51 \%$ whereas the maximum by the digestive gland in $P$. amurensis was $81 \%$. In contrast, absorption of Cd from organically coated particles by $M$. balthica exceeded that of $P$. amurensis during the early (intestinal) phase of digestion (Table 5). Intestinal digestion is also longer in $M$. balthica $(20 \mathrm{~h}$ ) than in $P$. amurensis ( $3 \mathrm{~h})$.

The effect of metal particle type on metal absorption was generally similar between Potamocorbula amurensis and Macoma balthica, despite their differences in digestive retention and processing. Neither species absorbed $\mathrm{Cr}$ efficiently from $\mathrm{HFO}, \mathrm{Si}_{\text {, }}$ or humic substances, no matter how the particles were digested. Both species absorbed Cd over a similar range of efficiency from these particles. Both clams assimilated $\mathrm{Cd}$ from $\mathrm{HFO}$ because of enhanced particle retention. $M$. balthica assimilated a little more $\mathrm{Cd}$ than $P$. amurensis from organics in experiments with low Cd loading, but was not as responsive to higher loadings.

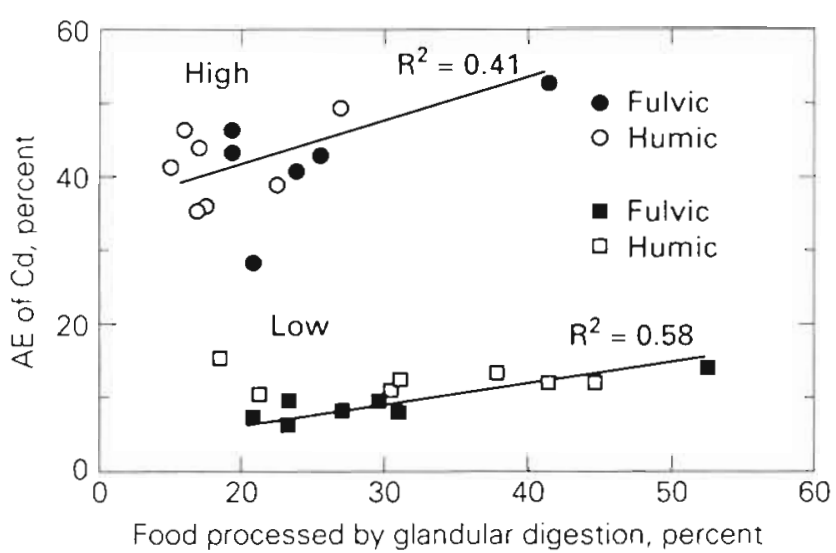

Fig. 6. Potamocorbula amurensis. Comparison of the effect of glandular digestion on the absorption of $\mathrm{Cd}$ by bivalve individuals when fed organic (humic or fulvic acid) coated hydrous ferric oxide particles with high or low loadings of bound $\mathrm{Cd}$. Percent absorption efficiency (\% AE) of individual bivalves was plotted against the amount of ingested food processed by glandular digestion. High: high Cd loading; Low: low Cd loading

\section{DISCUSSION}

Both geochemical and biological processes interacted to control the absorption efficiency of metals from particulate foods in bivalves. $\mathrm{AE}$ of $\mathrm{Cd}$ and $\mathrm{Cr}$ ranged from 1 to $62 \%$ in individuals of Potamocorbula amurensis and Macoma balthica. Factors contributing to the differences in $\mathrm{AE}$ included the chemical properties of the metal, the geochemical nature of the particle, the sorbed concentration of metal, and digestive partitioning of food particles.

Absorption of Cr was low from all the types of abiotic particles, in both bivalves, probably because of overriding geochemical factors. $\mathrm{Cr}$ (III) has a high affinity for oxygen-donor ligands. It preferentially sorbs strongly with HFO surfaces (Nakayama et al. 1981, Leckie et al. 1984), and has a very low solubility (Sass \& Rai 1987). Some of the Cr(III) may have been in the form of $\mathrm{Cr}(\mathrm{OH})_{3}$ or in the process of forming a solid solution with the $\mathrm{Fe}(\mathrm{OH})_{3}$. Both could further decrease the solubility and bioavailability of $\mathrm{Cr}$ (III). $\mathrm{Cr}$ (III) also forms complexes with organic ligands (Nakayama et al. 1981), although the nature of these complexes is not well understood. Humic organic coatings slightly enhanced $\mathrm{Cr}$ bioavailability to Potamocorbula amurensis and Macoma balthica. However, the generally low $\mathrm{AE}$ for all these forms of Cr suggests that little of this element would be transferred from any of these particle types to detritus-feeding bivalves.

Differences in metal chemistry may explain why ingested $\mathrm{Cd}$ was of greater bioavailability to Pota- 
mocorbula amurensis and Macoma balthica than $\mathrm{Cr}$. Cadmium sorbs to many types of surfaces (Leckie et al. 1984) and to humic acids (Kerndorf \& Schnitzer 1980), but with less intensity than $\mathrm{Cr}$. The formation of strong Cd-chloro complexes in seawater (Mantoura 1981, Valenta et al. 1987) and competition with $\mathrm{Ca}$ and $\mathrm{Mg}$ further reduce the complexation of $\mathrm{Cd}$ with humic substances (Mantoura et al. 1978, Tipping \& Hurley 1992) and its sorption to HFO (Cowan et al. 1991).

Very high loadings enhanced absorption efficiency of Cd from organically coated particles, especially in Potamocorbula amurensis. This geochemical effect was not related to saturation of the organic binding sites. Humic substances have a high content of oxygen-donor ligand, such as carboxyls and phenolic $\mathrm{OH}$ groups, that are not easily saturated in natural waters. The concentration effect was more likely due to a difference in binding intensity. Humic substances have a mixture of binding sites that complex metals over a continuum of binding energies. They have a relatively low content of $\mathrm{N}$ - and $\mathrm{S}$-containing ligands that strongly complex metals such as $\mathrm{Cd}$. The abundant oxygen-donor ligands complex metals with relatively low intensity (Kerndorf \& Schnitzer 1980), except when cationic metals form strong inner-sphere coordination bonds with electron donor groups of the humic molecules (Rashid et al. 1972). Overall binding energy decreases as metal loading increases (Perdue 1989, De Wit et al. 1990). Maes et al. (1992) reported that conditional complexation constants of $\mathrm{Cd}$ on humic substances decrease by about $0.15 \log K_{1}$ units for each 10 -fold increase in $\mathrm{Cd}$ loading. The difference in concentrations between low $\mathrm{Cd}$ and high $\mathrm{Cd}$ concentrations was 100 -fold in our experiments, enough to decrease $0.3 \log K_{1}$ units. Such a difference apparently was enough to enhance absorption of $\mathrm{Cd}$ in the digestive tract of $P$. amurensis and, perhaps, Macoma balthica. Effects on desorption were also evidenced by more efficient removal of $\mathrm{Cd}$ during intestinal digestion. The lack of difference in Cd absorption efficiency between FA and HA was not consistent with this explanation, since the total number of FA sites was less than HA sites. Steric effects or binding intensities could have differed between the 2 types of humic substance, however. The latter is consistent with the higher distribution coefficients observed at the end of adsorption for FA than HA, especially per unit organic carbon.

The absorption of $\mathrm{Cd}$ from $\mathrm{HFO}$-coated particles was influenced by biological processes. The more intensive digestion of the inorganic particles, correlated with a higher absorption efficiency of the element, implied that selectivity of particles for particular digestive pathways depended on the specific physical or chemical characteristics of the particle. Macoma balthica appeared less flexible in processing high proportions of food particles for intensive digestion than did Potamocorbula amurensis

Differences in digestive partitioning may explain what differences were observed between Macoma balthica and Potamocorbula amurensis. For example, higher $\mathrm{Cd}$ absorption from uncoated HFO than organically-coated HFO (at low Cd loadings) coincided with differences in digestive processing in both species. The lack of difference in AE between uncoated and organically coated Si in $M$. balthica (in contrast to $P$. amurensis) was coincident with a lack of difference in digestive processing. $M$. balthica accumulated $\mathrm{Cd}$ by absorption in the intestine and limited particle retention in the digestive gland. Less Cd was absorbed in the intestine of $P$. amurensis but a larger proportion of food was partitioned to the digestive gland where metal absorption is most efficient. Thus overall gut retention was not the critical factor when comparing absorption mechanisms between the 2 species, but differences in digestive partitioning of food particles were important.

Several previous studies have shown that when humic acids are adsorbed onto oxides, they can effectively mask the properties of the underlying phase (Tipping 1981, 1986, Tipping \& Heaton 1983). If we consider absorption efficiency as a geochemical probe, our data for most experiments are consistent with this idea. When particles were coated with humic substances, metal bioavailability to clams was significantly different in many experiments, compared to the metal bioavailabilities from uncoated particles. When humic substances are associated with different mineral surfaces such as $\mathrm{Si}$ or HFO, the binding of functional groups with the surface ligands of the mineral can result in differences in the steric conformation of the humic molecule. This can affect what ligands are available and the binding strength of those ligands (Francois 1990). Steric differences may have caused some of the differences observed between treatments in our study (i.e. less concentration effect in Cd absorption efficiency from organic-coated Si), but consistent steric effects were not observed among all treatments.

In summary, the present study showed that inorganic particles, and particles coated with humic substances such as humic and fulvic acids, can act as a trophic link, although not highly efficient, in the transfer of $\mathrm{Cd}$ to consumer animals under oxidized conditions in estuarine and marine environments. Both geochemical and biological processes interact to affect the food chain transfer of $\mathrm{Cd}$ under these conditions. Inorganic and organic-coated particles act more predominantly as a trophic sink for $\mathrm{Cr}$ (III) in oxidized sediments. Some of the variability in the bioavailability of particle-bound metals may relate to the complex nature of metal reactions with humic substances. 
Acknowledgements. We thank Dr G. Aiken (USGS, Boulder, $\mathrm{CO}$ for technical advice on humic substance extraction procedures, S. Griscom (USGS, Menlo Park, CA) for assistance in experimental procedures and data analysis, and D. Cain (USGS, Menio Park), W. Wang (MSRC, SUNY-Stony Brook, NY), Drs D. Kent and M. Kohler (USGS, Menlo Park) for helpful comments on the manuscript. D. Kent helped greatly with chemical interpretations, including estimations of site densities. Errors, of course, are ours and not attributable to reviewers. Mention of brand name products does not constitute an endorsement by the U.S. Geological Survey

\section{LITERATURE CITED}

Amiard, J. C. (1978). Modalités de la contamination d'une chaine trophique marine benthique par l'argent $110 \mathrm{~m} .3$. Influence du mode de contamination sur l'organotropisme du radionucléide. Helgoländer wiss. Meeresunters. 31: $444-456$

Amiard, J. C. (1992). Bioavailability of sediment-bound metals for benthic aquatic organisms. In: Vernet, J. P. (ed.) Impact of heavy metals on the environment. Elsevier Press, New York, p. 183-202

Borchardt, T. (1983). Influence of food quantity on the kinetics of cadmium uptake and loss via food and seawater in Mytilus edulis. Mar. Biol. 76: 67-76

Bricelj, V. M., Bass, A. E., Lopez, G. R. (1984). Absorption and gut passage time of microalgae in a suspension feeder: an evaluation of the ${ }^{51} \mathrm{Cr}:{ }^{14} \mathrm{C}$ twin tracer technique. Mar. Ecol. Prog. Ser. 17: 57-63

Brown, F. S., Baedecker, M. J., Nissenbaum, A., Kaplan, I. R. (1972). Early diagenesis in a reducing fjord, Saanich Inlet, British Columbia. IIl. Changes in organic constituents of sediments. Geochim. Cosmochim. Acta 36: 1185-1203

Bryan, G. W., Langston, W. J. (1992). Bioavailability, accumulation and effects of heavy metals in sediments with special reference to United Kingdom estuaries: a review. Environ. Pollut. 76: 89-131

Calow, P., Fletcher, C. R. (1972). A new radiotracer technique involving ${ }^{14} \mathrm{C}$ and ${ }^{51} \mathrm{Cr}$ for estimating the assimilation efficiency of aquatic primary producers. Oecologia 9: $155-170$

Cowan, C. E., Zachara, J. M., Resch, C. T. (1991). Cadmium adsorption on iron oxides in the presence of alkaline earth elements. Environ. Sci. Technol. 25: 437-446

Decho, A. W., Luoma, S. N. (1991). Time-courses in the retention of food material in the bivalves Potamocorbula amurensis and Macoma balthica: significance to the absorption of carbon and chromium. Mar. Ecol. Prog. Ser. 78: $303-314$

De Wit, J. C. M., Van Riemsdijk, W. H., Nederlof, M. M., Kinniburgh, D. G, Koopal, L. K. (1990). Analysis of ion binding on humic substances and the determination of intrinsic affinity distributions. Analyt. Chim. Acta 232: 189-207

DiToro, D. M., Mahony, J. D., Hansen, D. J., Scott, K. J., Hicks, M. B., Mayr, S. M., Redmond, M. S. (1990). Toxicity of cadmium in sediments: the role of acid volatile sulfide. Environ. Toxicol. Chem 9: 1487-1502

Douglas, G. S., Quinn, J. G. (1989). Geochemistry of dissolved chromium-organic matter complexes in Narragansett Bay interstitial waters. Adv. Am. Chem. Soc. Ser. 219: 297-320

Dzomback, D. A., Morel, F. M. M. (1990). Surface complexation modeling: hydrous ferric oxide. John Wiley \& Sons, New York

Edwards, M., Benjamin, M. M. (1989). Adsorptive filtration using coated sand: a new approach for treatment of metal bearing wastes. J. Water Pollut. Control Fed. 61 . $1523-1533$

Fisher, N. S., Nolan, C. V., Fowler, S. W. (1991). Assimilation of metals in marine copepods and its biogeochemical implications. Mar. Ecol. Prog. Ser. 71. 37-43

Francois, R. (1990). Marine sedimentary humic substances: structure, genesis, and properties. Rev. aquat. Sci. 3 $41-80$

Harvey, R. W., Luoma, S. N. (1985a). Effect of adherent bacteria and bacterial extracellular polymers upon assimilation by Macoma balthica of sediment-bound $\mathrm{Cd}, \mathrm{Zn}$ and $\mathrm{Ag}$. Mar. Ecol. Prog. Ser. 22: 281-289

Harvey, R. W., Luoma, S. N. (1985b). Separation of solute and particulate vectors of heavy metal uptake in controlled suspension-feeding experiments with Macoma balthica. Hydrobiologia 121: 97-102

Johns, C., Luoma, S. N., Elrod, V. (1988). Selenium accumulation in benthic bivalves and fine sediments of San Francisco Bay, the Sacramento-San Joaquin Delta, and selected tributaries. Estuar. coast. Shelf Sci. 27: 381-396

Jones, G. B., Jordan, M. B. (1979). The distribution of organic material and trace metals in sediments from the River Liffey Estuary, Dublin. Estuar. coast. mar. Sci. 8: 37-47

Kerndorf, H., Schnitzer, M. (1980). Sorption of metals on humic acid. Geochim. Cosmochim. Acta 44: 1701-1708

Leckie, J. O., Appleton, A. R., Ball, N. B., Halyes, K. F. (1984). Adsorption removal of trace elements from fly ash pond effluents onto iron oxyhydroxide. Final Report, EPRI RP910-10. Electric Power Research Institute, Palo Alto

Lopez, G. R., Cheng, I.-J. (1983). Synoptic measurements of ingestion rate, ingestion selectivity, and absorption efficiency of natural foods in the deposit-feeding molluscs Nucula annulata (Bivalvia) and Hydrobia totteni (Gastropoda). Mar. Ecol. Prog. Ser. 11: 55-62

Lopez, G. R., Tantichodok, P., Cheng, I.-J. (1989). Radiotracer methods for determining utilization of sedimentary organic matter by deposit feeders. In: Lopez, G. R., Taghon, G., Levinton, J. (eds.) Ecology of marine deposit feeders. Lecture notes on coastal and estuarine studies, Vol. 31. Springer-Verlag, New York, p. 149-170

Luoma, S. N. (1990). Processes affecting metal concentrations in estuarine and coastal marine sediments. In: Rainbow, P. S., Furness, R. W. (eds.) Heavy metals in marine environments. Uniscience. CRC Press, Boca Raton, p. 52-66

Luoma, S. N., Carter, J. L. (1993). Understanding the toxicity of contaminants in sediments: beyond the bioassay-based paradigm. Environ. Toxicol. Chem. 12: 793-796

Luoma, S. N., Davis, J. A. (1983). Requirements for modeling trace metal partitioning in oxidized estuarine sediments. Mar. Chem. 1.2: 159-181

Luoma, S. N., Jenne, E. A. (1976). Factors affecting the availability of sediment-bound cadmium to the estuarine deposit-feeding clam, Macoma balthica. In: Cushing, E. (ed.) Radioecology and energy resources: Proc. 4th Nat. Symp. on Radioecology. Fed. Soc. Am. Spec. Publ. No. 1, Dowden, Hutchinson \& Ross, Inc., Stroudsberg, PA, p. $283-291$

Luoma, S. N., Johns, C., Fisher, N. S., Steinberg, N. A., Oremland, R. S., Reinfelder, J. R. (1992). Determination of selenium bioavailability to a benthic bivalve from particulate and solute pathways. Environ. Sci. Technol. 26: 485-491

MacCarthy, J. F, Jiminez, B. D. (1985). Reduction in bioavailability to bluegills of polycyclic aromatic hydrocarbons bound to dissolved humic material. Environ. Toxicol. Chem. 4: 511-521

MacCarthy, P., Suffet, I. H. (1989). Introduction: aquatic humic substances and their influences on the fate and 
treatment of pollutants. Adv. Am. Chem. Soc. Ser. 219: $107-114$

MacFarlane, R. B. (1978). Molecular weight distribution of humic and fulvic acids of sediments from a north Florida estuary. Geochim. Cosmochim. Acta 42: 1579-1582

Maes, A., van Herreweghen, E., van Elewijck, F., Cremers, A. (1992). Behaviour of trace cadmium in boom clay reducing sediment. I. Complexation with in situ dissolved humic acids. Sci. Total Environ. 117/118: 463-473

Mantoura, R. F. C. (1981). Organo-metallic interactions in natural waters. In: Dursma, E. K., Dawson, R. (eds.) Marine organic chemistry. Elsevier, New York, p. 179-224

Mantoura, R. F. C., Dickson, A., Riley, J. P. (1978). The complexation of metals with humic materials in natural waters. Estuar. coastal mar. Sci. 6: $387-408$

Martoja, R., Ballan-Dufrancais, C., Jeantet, A.-Y., Gouzerh, P., Amiard, J.-C., Amiard-Triquet, C., Berthet, B., Baud, J.-P. (1988). Effets chimiques et cytologiques de la contamination expérimentale de l'huitre Crassostrea gigas Thunberg par l'argent administré sous forme dissoute et par voie alimentaire. Can. J. Fish. Aquat. Sci. 45: 1827-1841

Mayer, L. M. (1982). Aggregation of colloidal iron during estuarine mixing. Kinetics, mechanism and seasonality. Geochim. Cosmochim. Acta 46: 2527-2535

Mayer, L. M. (1989). Geochemistry of humic substances in estuarine environments. In: Aiken, G. R., McKnight, D. M., Wershaw, R. L., MacCarthy, P. (eds.) Humic substances in soil, sediment and water. John Wiley \& Sons, New York, p. $211-232$

Mayer, L. M., Schick, L. L., Chang, C. A. (1983). Kinetics of trivalent chromium complexation and adsorption at the river-estuary interface. Implications for reactive pollutant transport. In: Proc. int. Conf. Heavy Metals Environ., CEP Consultants, Edinburgh, p. 1112-1115

Nakayama, E., Kuwamoto, T., Tsurubo, S., Fuinaga, T (1981). Chemical speciation of chromium in seawater. Effect of naturally occurring organic materials on the complex formation of chromium(III). Analyt. Chim. Acta 130: 289-294

Nichols, F. H., Thompson, J. K., Schemel, L. E. (1990). Remarkable invasion of San Francisco Bay (California, USA) by the Asian clam Potamocorbula amurensis. II. Displacement of a former community. Mar. Ecol. Prog. Ser. 66: 95-101

Perdue, E. M. (1989). Effects of humic substances on metal speciation. Adv. Am. Chem. Soc. Ser. 219: 281-295

Preston, M. R. (1979). An investigation into the behaviour of humic compounds in estuaries. Ph.D. thesis, Univ. Liverpool

Rashid, M. A. (1985). Geochemistry of marine humic compounds. Springer-Verlag, New York

Rashid, M. A., Buckley, D. E., Robertson, K. R. (1972). Interactions of a marine humic acid with clay minerals and a natural sediment. Geoderma 8: 11-19

Reinfelder, J. R., Fisher, N. S. (1991). The assimilation of elements ingested by marine copepods. Science 251. $794-796$

Rice, J. A., MacCarthy, P. (1989). Characterization of a stream sediment humin. J. Am. Chem. Soc. 219: 41-54

Sadiq, M. (1992). Toxic metal chemistry, Marcel Dekker, Inc., New York

Sass, B. M., Rai, D. (1987). Solubility of amorphous
This article was presented by S. W. Fowler (Senior Editorial Advisor), Monaco
chromium(IIl) and Iron(III) hydroxide solid solutions Inorg. Chem. 26: 2228-2232

Sholkovitz, E. R., Boyle, E. A., Price, N. B. (1978). The removal of dissolved humic acids and iron during estuanne mixing. Earth Planet. Sci. Lett. 40: 130-136

Sick, L. V., Baptist, G. J. (1979). Cadmium incorporation by the marine copepod Pseudodiaptomus coronatus. Limnol. Oceanogr. 24: 453-462

Sokal, R. R., Rohlf, F. J. (1981). Biometry. 2nd edn. W. H. Freeman \& Co., San Francisco

Steele, R. G. D., Torrie, J. H. (1980). Principle and procedures of statistic. A biometric approach, 2nd edn. McGraw-Hill Co., New York

Swartz, R. C., Ditsworth, G. R., Schults, D. W., Lamberson, J. O. (1985). Sediment toxicity to a marine infaunal amphipod: cadmium and its interaction with sewage sludge. Mar. environ. Res. 18: 133-153

Tessier, A., Couillard, Campbell, P. G. C., Auclair, J. C. (1993). Modeling $\mathrm{Cd}$ partitioning in oxic lake sediments and $\mathrm{Cd}$ burdens in the freshwater bivalve Anodonta grandis (Mollusca, Pelecypoda). Limnol. Oceanogr. 38: 1-18

Thurman, E. M., Malcolm, R. L. (1981). Preparative isolation of aquatic humic substances. Environ. Sci. Technol. 15: $463-466$

Timmermans, K. R., Spijkerman, E., Tonkes, M., Govers, H. (1992). Cadmium and zinc uptake by two species of aquatic invertebrate predators from dietary and aqueous sources. Can J. Fish. Aquat. Sci. 49: 655-662

Tipping, E. (1981). The adsorption of aquatic humic substances by iron oxides. Geochim. Cosmochim. Acta 45: $191-199$

Tipping, E. (1986). Some aspects of the interactions between particulate oxides and aquatic humic substances. Mar. Chem. 18: 161-169

Tipping, E., Heaton, M. J. (1983). The adsorption of aquatic humic substances by two oxides of manganese. Geochim. Cosmochim. Acta 47: 1393-1397

Tipping, E., Hurley, M. A. (1992). A unifying model of cation binding by humic substances. Geochim. Cosmochim. Acta 56: $3627-3641$

Valenta, P., Breder, R., Mart, L., Rutzel, H. (1987). Distribution of $\mathrm{Cd}$ and $\mathrm{Pb}$ between dissolved and particulate phases in estuaries. Toxicol. environ. Chem. 14:129-141

van Hattum, B., de Voogt, P., van den Bosch, L., van Straalen, N. M., Joosse, E. N. G. (1989). Bioaccumulation of cadmium by the freshwater isopod Asellus aquaticus (L.) from aqueous and dietary sources. Environ. Pollut. 62: 129-151

van Klump, J., Krezoski, J. R., Smith, M. E., Kaster, J. L. (1987). Dual tracer studies of the assimilation of an organic contaminant from sediments by deposit feeding oligochaetes. Can. J. Fish. Aquat. Sci. 44: 1574-1583

Widdows, J., Fieth, P., Worrall, C. M. (1979). Relationship between seston, available food and_feeding activity in the common mussel Mytilus edulis. Mar. Biol. 50: 195-207

Wikfors, G. H., Ukeles, R. (1982). Growth and adaptation of estuarine unicellular algae in media with excess copper, cadmium or zinc, and effects of metal-contaminated algal food on Crassostrea virginica larvae. Mar. Ecol. Prog. Ser. 7: 191-206

Wilkinson, L. (1987). SYSTAT: the system for statistics. Systat, Inc., Evanston, IL.

Manuscript first received: September 29, 1993

Revised version accepted: February 17, 1994 